\title{
Wire-guided over-the-scope clip method for closing gastrobronchial fistula
}

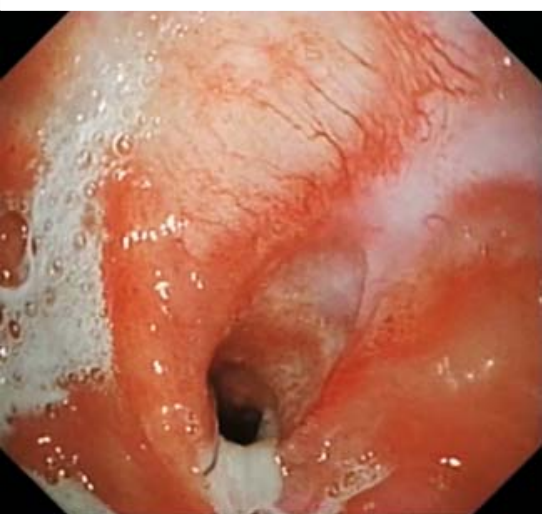

- Fig. 1 Endoscopic view of fibrotic fistula orifice in the proximal fundus.

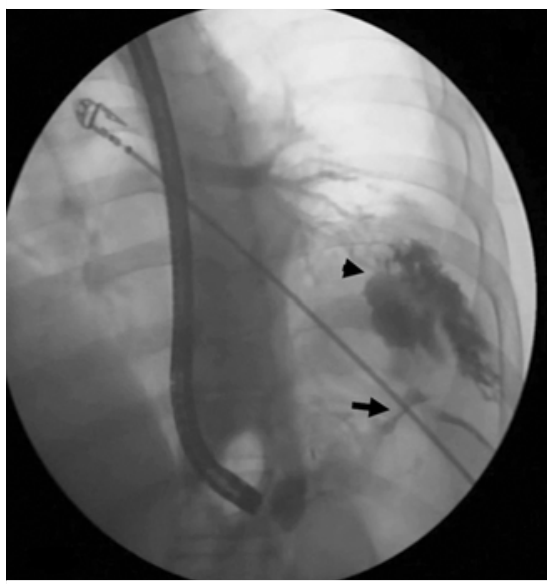

- Fig. 2 Fistulography showed leakage of contrast medium into the subdiaphragmatic area (arrow) and the left bronchus (arrowhead).

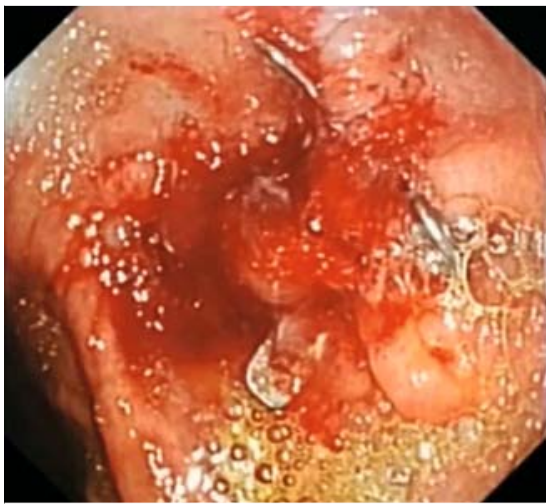

- Fig. 3 On endoscopy, the fistula orifice appeared to be completely closed.

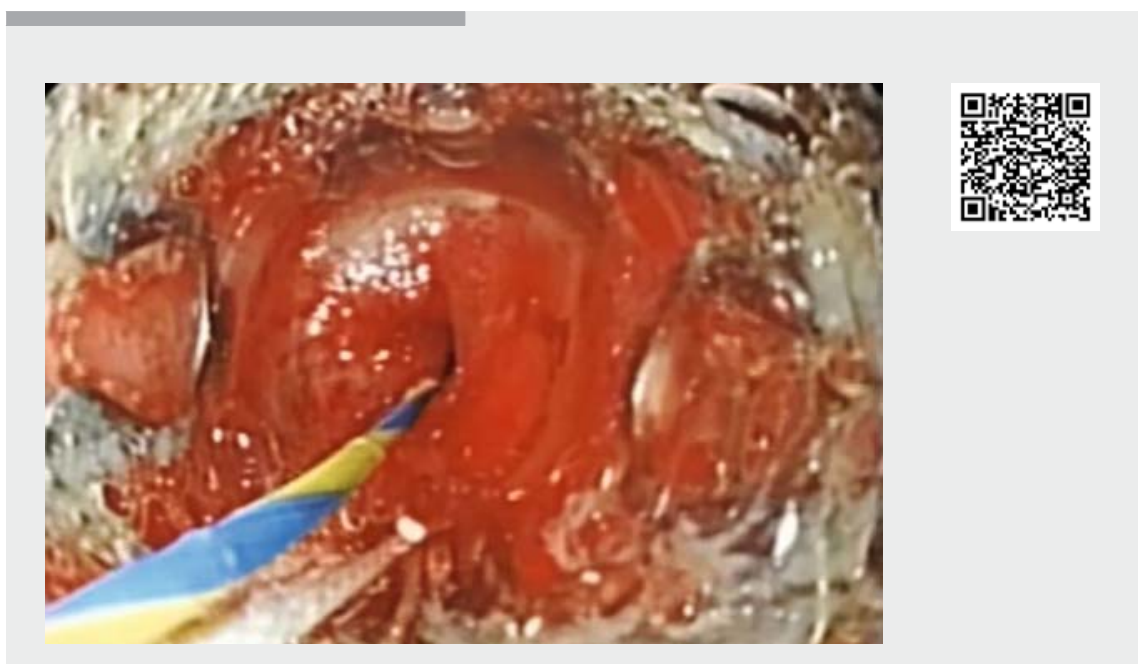

$\checkmark$ Video 1 The wire-guided technique for closure by over-the-scope clip.

Gastric fistula is a significant complication that develops in $0.9 \%-2.6 \%$ of cases after bariatric surgery [1]. Although gastrobronchial fistula (GBF) is a rare gastric fistula, it can generally be treated with thoracotomy and laparotomy but with high mortality rates.

A 52-year-old man who had undergone a mini-gastric bypass operation (preoperative body mass index $38 \mathrm{~kg} / \mathrm{m}^{2}$ ) 4 months earlier was admitted to our hospital with GBF and secondary complications. Endoscopic evaluation revealed a fibrotic fistula orifice, approximately $7-8 \mathrm{~mm}$ in diameter, in the proximal fundus ( $\triangleright$ Fig. $\mathbf{1}$ ). A balloon catheter loaded with a guidewire was inserted into the fistula tract. Fistulography showed leakage of contrast medium into the left subdiaphragmatic area and left bronchus ( $\triangleright$ Fig. 2 ). After checking the cavity with the balloon, the wire was left in the fistula tract and the endoscope was removed ( $\vee$ Video 1 ). The endoscope was loaded with a 12-mm over-the-scope clip (OTSC) and reinserted into the fistula tract over the wire. The OTSC was deployed and the fistula orifice was closed, with the wire in the center of the clip. The wire was re- moved easily from the middle of the clip. Fluoroscopy confirmed no contrast leakage into the fistula tract, and endoscopy showed the fistula orifice to be totally closed ( $\triangleright$ Fig. 3 ). The patient was completely well during the first year of follow-up.

Unlike classical closure methods, the OTSC method used in this case involved wire guidance, with the wire still in place when the fistula orifice was closed. This wire-guided OTSC method, which has been reported previously [2], was preferred to the use of the OTSC Anchor and Twin Grasper (Ovesco, Tübingen, Germany) because it reduces the mobility of the OTSC through close proximity to the lumen wall, and suction can be performed without damage to fibrotic tissue.

Endoscopy_UCTN_Code_TTT_1AO_2AI

\section{Competing interests}

The authors declare that they have no conflict of interest. 
The authors

\section{Bulent Odemis, Dilara Turan Gökçe}

Department of Gastroenterology, Ankara City Hospital, Ankara, Turkey

\section{Corresponding author}

\section{Dilara Turan Gökçe, MD}

Department of Gastroenterology, Ankara City Hospital, Bilkent Boulevard No: 1 , Ankara 06105, Turkey

Fax: +90-543-5484378

dilaraturan89@yahoo.com

\section{References}

[1] Abou Rached A, Basile M, El Masri H. Gastric leaks post sleeve gastrectomy: review of its prevention and management. World J Gastroenterol 2014; 20: 13904-13910

[2] Tabibian JH, Kochman ML. Over-the-wire technique to facilitate over-the-scope clip closure of fistulae. Gastrointest Endosc 2017; 85: 454-455

Bibliography

Endoscopy 2021; 53: E42-E43

DOI 10.1055/a-1177-9952

ISSN 0013-726X

published online 2.6.2020

(c) 2020. Thieme. All rights reserved.

Georg Thieme Verlag KG, Rüdigerstraße 14,

70469 Stuttgart, Germany

\section{ENDOSCOPY E-VIDEOS}

https://eref.thieme.de/e-videos

回回 Endoscopy E-Videos is a free access online section, reporting 回和: on interesting cases and new techniques in gastroenterological endoscopy. All papers include a high quality video and all contributions are freely accessible online.

This section has its own submission website at

https://mc.manuscriptcentral.com/e-videos 